\title{
The Analysis of Election Criminal Actions Around 2019 in Banjarnegara
}

\author{
Endro Wibowo $\mathrm{Aji}^{*)}$ and Rakhmat Bowo Suharto ${ }^{* *}$ \\ ${ }^{*}$ Student Master of Law, Faculty of Law, Universitas Islam Sultan Agung Semarang, E-mail: \\ endrowibowo83@gmail.com \\ ${ }^{* *}$ Lecturer of Faculty of Law, Universitas Islam Sultan Agung Semarang
}

\begin{abstract}
The purpose of this research is to find out what factors are hindering in enforcing the 2019 election criminal law in Banjarnegara Regency and how the solution is carried out by the Bawaslu of Banjarnegara Regency in enforcing the election criminal law in 2019. The research method is taken using sociological juridical with descriptive specifications done to retrieve the facts that happened. The results showed that in the administration of elections, law enforcement against criminal acts in legislative elections encountered many obstacles such as: the failure to fulfill the formal and material requirements of the alleged violation of election criminal acts, both from the findings of supervisors and public reports, made it difficult to follow up on the alleged violations; multi-interpretative regulations cause human resource difficulties in applying the articles that must be suspected in suspected election violations; disagreements between institutions in the integrated law enforcement center (Gakkumdu); limited time for handling election crimes. Bawaslu of Banjarnegara Regency in overcoming obstacles keeps trying as much as possible to follow up on suspected violations, maximizing preventive actions through various channels, media, and always coordinates both vertically with Bawaslu of Central Java Province and coordinates horizontally with all related parties in Banjarnegara Regency in the framework of minimize potential violations.
\end{abstract}

Keywords: Crime; General Election; Supervisor's Findings.

\section{Introduction}

The development of democracy in Indonesia after the collapse of the New Order until now has developed the thoughts of the people to implement the principle of people's sovereignty in various ways, so that in every aspect of life as a state the values of people's sovereignty are always the heart that pumps blood throughout the body of the Republic of Indonesia. Historically, the development of people's sovereignty, which initially had limited participation in legislative elections starting in 2004, has developed, the people are not only limited to the scope of legislative elections but also the scope of election for the executive branch starting from the scope of the highest executive branch, namely the president, to regional head elections.

Direct general election by the people is a means of manifesting the people's sovereignty in order to produce a democratic state government based on Pancasila and the 1945 Constitution. The 1945 Constitution in Article 1 paragraph (2) states that "sovereignty is in the hands of the people and is implemented according to Law Basic Law". Implementation of direct, general, free, secret, honest and fair elections is a form of public participation in exercising their sovereignty.

According to Achmad Sulchan in Sri Herlina and Umar Ma'ruf (2019) Election is to realize people's sovereignty in the country in the framework of the people in running state governance, not only aiming to elect representatives who will sit in the Legislative/representative institution, but also as a means of realizing livelihood 
preparations. a country imbued with the spirit of Pancasila and the 1945 Constitution within the Unitary State of the Republic of Indonesia. ${ }^{1}$

General election is the most tangible form of implementing democracy, therefore it must be protected from all election violations, and actions that are intended to make the general election undemocratic, namely, dishonest and unfair (Jurdil). The Election Supervisory Body or abbreviated as Bawaslu as one of the election management bodies in charge of supervising the implementation of elections has the authority to, among others, oversee the implementation of election stages, receive reports on alleged elections, suspected election violations, and follow up on findings or reports to agencies that authorized. Therefore, it is imperative for Bawaslu to coordinate with related parties, especially law enforcement agencies, namely the police and prosecutors.

In handling violations of election criminal offenses, Bawaslu based on law establishes an Integrated Law Enforcement Center (Gakkumdu). The Integrated Law Enforcement Center (Gakkumdu) according to Act No. 7 of 2017, Article 1 number 38, the Integrated Law Enforcement Center, hereinafter referred to as Gakkumdu, is the center for law enforcement activities for election criminal acts consisting of elements from Bawaslu, Provincial Bawaslu and/or Bawas/u. Regency/City, National Police of the Republic of Indonesia, Regional Police, and/or Resort Police, and Attorney General's Office of the Republic of Indonesia, High Prosecutor's Office, and/or District Prosecutors' Office.

Election criminal offenses in Act No. 7 of 2017 have increased in norms from the previous law. As for the increase in the number of norms for the forms of criminal acts, the number is 66 articles (Articles 488-544). ${ }^{2}$ The election, which was participated by many parties, caused party elites to take various actions to gain votes, and even did not hesitate to commit fraudulent acts that are included in the norms of election crimes, such as making promises, conducting money politics or involving prohibited parties as contained in Article 280 paragraph (2) of Act No. 7 of 2017.

Many reports and findings of election crimes have been submitted to Bawaslu but cannot be processed at a later stage or until a decision is made in court. According to data sources compiled by Bawaslu RI, reports and findings of alleged election criminal acts in 2019 totaled 582 cases and 337 decisions were processed at the court level. ${ }^{3}$ Bawaslu of Banjarnegara Regency itself has 14 suspected violations, only 1 of which has reached the decision process. This is due to many factors, one of which is the difficulty in determining the substance of the law, especially in the legal subject of election crimes.

Based on the description above, rthe formulation of the problem in this paper is what factors hinder in enforcing the 2019 election criminal law in Banjarnegara Regency and what is the solution made by Bawaslu of Banjarnegara Regency?

\footnotetext{
${ }^{1}$ Sri Herlina and Umar Ma'ruf, "Law Enforcement Against Elections Crime During Electoral Campaign 2019 (Case Study In Bawaslu of Banjarmasin City)”, Jurnal Daulat Hukum, Vol. 2 No 3, 2019 Unissula, Semarang. Http: //jurnal.unissula. ac.id/index.php/RH/article/view/5656/3381

${ }^{2}$ Minan, Ahsanul. (2019) Perihal Penegakan Hukum Pemilu. Jakarta: Bawaslu. p. 15

${ }^{3}$ Ratna Dewi Pettalolo, 2019, Perihal Penegakan Hukum Pemilu, Bawaslu, Jakarta, p. 50
} 
The purpose of this research is to find out what factors are hindering the enforcement of the 2019 election criminal law in Banjarnegara Regency and what is the solution made by Bawaslu of Banjarnegara Regency?

\section{Research methods}

The approach method used by the author in this research is the sociological juridical approach (social legal approach, with descriptive research specifications. The data collection method is carried out using the interview method and the literature method. The data analysis method used in this research is qualitative analysis.

\section{Results and Discussion}

The Indonesian state can be said to be a giant laboratory that is evolving. It is not surprising to see that the Republic of Indonesia has automatically chosen to use a democratic system since independence. ${ }^{4}$ The implementation of a post-independence democratic system by the founders of the Nation did not experience difficulties in holding elections, which has always been a government program to regulate the transfer of power. For a long time the idea was raised only in 1955 Indonesia could hold its first general election. It took a very long time to bring about elections due to political polemics. The peak of political upheaval in Indonesia was getting hotter when the number one person (Soeharto) was deposed from the throne on May 21, $1998 .{ }^{5}$

Ambiguous $^{6}$ is a democracy term. So the definition is not single, various countries that claim to be democratic countries have taken different paths. ${ }^{7}$ This proves that no country is truly (completely) democratic, and no country is truly (completely) authoritarian. Thus, the appearance of political configuration within a country can move along a continuum connecting two poles in the political spectrum, namely the poles of democracy and the poles of authoritarianism. It can be concluded, the political configuration of a country cannot be viewed as "black and white" to be called democracy or authoritarian. ${ }^{8}$

Election is a sign that Indonesia is a democratic country by giving full voice to the people the right to elect representatives directly and democratically. In Indonesia, a democratic system operates in general elections which are held directly, publicly, freely, secretly, honestly and fairly every five years. ${ }^{9}$

\footnotetext{
${ }^{4}$ Firmanzah, 2010. Persaingan, Legitimasi Kekuasaan, dan Marketing Politik, Jakarta: Erlangga, p. 65.

${ }^{5}$ Agam Primadi, David Efendi, Sahirin, The Role of Beginner Voters in Participatory Election Supervision (Case Study: Group of Bawaslu South Bawaslu Supervisory Agencies), JPI: Journal of Political Issues, Faculty of Social and Political Sciences, Bangka Belitung University, Vol. 1, No. 1, July 2019, p. 63.

${ }^{6}$ Budiardjo, Miriam. (1997). Dasar-Dasar Ilmu Politik. Jakarta: PT. Gramedia, p. 50. see Moh. Mahfud MD. (2018). Politik Hukum Di Indonesia, Ed. Rev. 8. Depok: Rajawali Pers. p. 23.

${ }^{7}$ Rais, M. Amien. (1986). Pengantar dalam Demokrasi dan Proses Politik. Jakarta: LP3ES. p. iii See Moh. Mahfud MD. (2018). Politik Hukum Di Indonesia, Ed. Revision 8, Depok: Rajawali Pers. p. 23.

${ }^{8}$ Moh. Mahfud MD. (2018). Politik Hukum Di Indonesia, Ed. Revision 8, Depok: Rajawali Pers. p. 25.

9 Iva Amiroch, Critical Study Relevance of Act No. 10 of 2016 with Government Regulation No. 151 of 2000, Jurnal Daulat Hukum $\quad$ Vol. 112018$)$ url:http://jurnal.unissula.ac.id/index.php/RH/article/view/3929/2791
} 
General elections or often referred to as elections are one of the characteristics that must exist in a democratic country. Henry B Mayo in the book Introduction to Democratic Theory defines a democratic political system, where public policy is determined on the basis of a majority by representatives who are effectively supervised by the people in periodic elections based on the principle of political equality and held in an atmosphere of guaranteeing freedom of political. ${ }^{10}$ Thus the Election is an important means for the people in the life of the state, namely by electing representatives who in turn will control the wheels of government. The results of general elections held in an atmosphere of openness with freedom of opinion and freedom of association are deemed to reflect fairly accurately reflect the aspirations and participation of the people.

According to Benjuino Theodore as quoted by Agus Riwanto, the term general election system or Election has a very strict definition, namely the general election system is a series of activities that are regulated according to laws and regulations which according to him there are 2 (two) major aspects in it, first, voters express their choice politically, both votes from voters can be interpreted as a power or a certain political seat/position. ${ }^{11}$

Elections are a constitutional mandate that must be carried out by the government, in this case guaranteeing and protecting the exercise of people's sovereignty in expanding political rights in elections. Election as one of the ongoing practices of power and governance must be based on legal principles with fairness and usefulness values. One of the basic principles of a democratic constitutional state is the guarantee of justice for the people to express their sovereignty. ${ }^{12}$

The electoral justice system is an important instrument for upholding the law and ensuring the full implementation of democratic principles through free, fair and honest elections. The electoral justice system was developed to prevent and identify irregularities in general elections, as well as the means and mechanisms to correct irregularities and impose sanctions on violators. ${ }^{13}$ As one of the prerequisites in achieving electoral justice is that the legal framework must be structured so that it is not ambiguous, easy to understand, open, and must be able to highlight all elements of the electoral system file needed to ensure democratic elections. ${ }^{14}$

Law enforcement is a concrete implementation stage of law-making. This stage is tantamount to the term law enforcement, but the term law enforcement is used more

\footnotetext{
${ }^{10}$ Masykurudin Hafidz, 2019. Menguatkan Partisipasi Masyarakat dalam Pengawasan Pemilu Serentak 2019. Jakarta, Bawaslu, p. 3

${ }^{11}$ Riwanto, Agus. (2016). Hukum Partai Politik dan Hukum Pemilu di Indonesia. Yogyakarta: Thafa Media. p. 53.

12 Nurul Fuji Sri Hastuti and Jawade Hafidz, "Implementation Of Article 240 Paragraph (1) Letters G Act No. 7 of 2017 In The Making Of Combating Corruption Crime In Legislative Institutions (Case Study in KPU of Central Java)", Jurnal Daulat Hukum Vo. 2 No. 2 (2019) url: http: //jurnal.unissula.ac.id/index.php/RH/article/view/3340/2469

${ }^{13}$ Ika Yuana Darmayanti, Law Politics Of Legislative Election, Jurnal Daulat Hukum Vol. 2, No 2 (2019), url:http://jurnal.unissula.ac.id/index.php/RH/article/view/5414/3341

${ }_{14}$ Veri Junaidi, et al, 2013, Election System Legal Politics: Portraits of Openness and Public Participation in the Formulation of Law Number 8 of 2012 concerning General Election of Members of DPR, DPD and $D P R D$, Jakarta: Perludem Foundation, page: iii.
} 
frequently. ${ }^{15}$ Law enforcement in general, there are several factors that have a positive and negative impact (constraints and obstacles) in law enforcement on election crimes. According to Soerjono Soekanto, there are five (5) factors that influence law enforcement, namely: ${ }^{16}$

- Factors of legislation, law itself.

- Law enforcement factors, the parties who form and implement the law.

- Facility factor or facilities to support law enforcement.

- Community factors, namely the environment in which they may apply or apply.

- Cultural factors, namely as the result of work, creativity, and feeling that underlie human initiatives in social life.

The 16th President of the United States Abraham Lincoln said that "ballots are much stronger than bullets" (Huizenga in M Afifudin: 2020). Ballot papers that present the vote of the people in elections have a big impact far beyond bullets that represent a tool of violence. ${ }^{17}$ Surbakti in M. Afifudin: 2020 said that political experts believe elections have several functions. First, as a mechanism for selecting state administrators. Second, elections have a function as a mechanism to delegate part of the people's sovereignty to election participants. Third, elections are a mechanism that can guarantee periodic political changes (elite circulation and changes in patterns and direction of public policies). fourth, elections as a means of conflict resolution by transferring various kinds of differences and conflicting interests in the community into the legislative and executive bodies to be discussed, debated, and resolved in an open and civilized manner. ${ }^{18}$

As soon as the election function is important, it must be maintained that elections are able to guarantee the legitimacy of democracy, this legitimacy can be achieved if the election fulfills the values of transparency, accountability, credibility and integrity, so that people trust and have confidence in the process and results of the election administration. ${ }^{19}$ The existence of an election supervisory agency is a characteristic feature of Indonesia which is experienced in holding democratic elections. Election supervision in other countries is carried out by the General Election Commission (KPU), which is the event organizer and election supervisor. Even in a number of countries, the KPU is given quasi-judicial "power" so that it can decide election violations. ${ }^{20}$ Institutionally, election supervisors consist of Bawaslu, Provincial Bawas/u and Regency/City Bawaslu. Article 95 letters a, b, and c of the Election Law stipulate that Bawaslu has the authority to receive and follow up on reports related to suspected violations of the implementation of laws and regulations concerning Elections, examine, review and decide violations of Election administration, examine, review, and pursue election criminal offenses.

\footnotetext{
${ }^{15}$ Satjipto Raharjo, 2012. Ilmu Hukum Cetakan ke VII, PT Cipta Aditya Bakti, Bandung, p. 191.

${ }^{16}$ Soerjono Soekanto, 2012, Faktor yang Mempengaruhi Penegakan Hukum, Jakarta: Rajawali Press, p. 12,34 and 45

${ }^{17}$ M. Afifudin. (2020). Membumikan Pengawasan Pemilu. Jakarta: Kompas Gramedia. p. 1.

18 Ibid. p. 2.

19 Ibid.

${ }^{20}$ Harun Husein, Indonesian Election; 2014. Pemilu Indonesia; Fakta, Angka, Analisis, dan Studi Banding. Perludem, Jakarta, p. 600
} 
Basically, election criminal law enforcement is divided into two (2) categories: criminal offenses and criminal offenses. With the procedural law mechanism, it also displays short examination procedures and routine examinations. Especially for election crimes, then permanently at the judicial level with the decision of the High Court being final and binding. ${ }^{21}$ In addition, a special investigative police officer and a special prosecutor are assigned to the election supervisor, whose task is to directly process suspected election violations.

Election crime is a type of criminal act regulated in the Criminal Code, although it is further regulated in various Election Laws, therefore election crimes are considered special crimes. Elections are held once every five years and election criminal acts occur during the Election period every five years. Even though it is only held once every five years, an election must not be flawed and tarnished, and anyone who tarnishes or tries to tarnish an election is very appropriate if it is dealt with firmly. ${ }^{22}$

Election criminal acts are handled in separate ways and procedures that refer to Bawaslu Regulation Number 31 of 2018 concerning Integrated Law Enforcement Centers. ${ }^{23}$ Technically it is also known as repression. The process of prosecuting election crimes is carried out in 4 (four) main stages which include: receipt of reports or findings; first discussion; second discussion; the third discussion; and the fourth discussion. $^{24}$

According to Yudhi Atmaja and Ira Alia Maerani, the inhibiting factor in enforcing election violations states that there are no statutory provisions that still limit the Election Supervisory Agency (Bawaslu) in maximizing its role. This is due to regulatory factors, Bawaslu is not authorized to call the clarification process. and the obligation to prepare at least 2 (two) pieces of evidence in forwarding recommendations. The intensity of attendance between agencies is still weak in handling violations in a short time. ${ }^{25}$

At the 2019 General Election, Bawaslu of Banjarnegara Regency handled 14 findings and reports of suspected violations. Of the 14 findings or reports of alleged violations, only 1 has reached the court verdict.

The factors that hinder the Banjarnegara Regency Bawaslu in enforcing the law against criminal acts in the 2019 Concurrent Election according to the Election Supervisory Board of Banjarnegara Regency include, first, fulfilling formal and material requirements related to suspected election violations, namely related to evidence in the form of witnesses and evidence of cases of suspected election violations. The failure to fulfill witnesses and evidence makes the case must be stopped. The obstacle that causes difficulty in fulfilling witnesses is due to the lack of public participation in upholding election law. Bawaslu does not have an element of forced summons so that

\footnotetext{
${ }^{21}$ Nur Muchammad, Munsharif Abdul Chalim, Analysis of Criminal Liability Crime of Legislative Elections (Case Study of Legislative Elections in Semarang), Jurnal Daulat Hukum Vol.2 No 4 (2019) url: http: //jurnal.unissula.ac.id/index.php/RH/article/view/4210/2916

${ }_{22}$ Mulyadi, Dedi. (2012). Kebijakan Legislasi Tentang Sanksi Pidana Pemilu Legislatif Di Indonesia Dalam Perspektif Demokrasi. Jakarta: Gramata Publising. p. 08

${ }^{23}$ Ratna Dewi Pettalolo, 2019. Perihal Penegakan Hukum Pemilu, Bawaslu, Jakarta, p.46

${ }^{24}$ Ibid. p. 46

${ }^{25}$ Yudhi Atmaja, Ira Alia Maerani, Money Politics In The Electoral Law And The Law Of Election, Jurnal Daulat Hukum Vo. 2 No. 2 (2019) url:http://jurnal.unissula.ac.id/index.php/RH/article/view/5546
} 
if the community is not willing to become witnesses, the case being handled must be stopped. In addition, the public's participation in reporting suspected violations to the election supervisory agency is still very low. This can be seen from the 14 cases handled by Bawaslu of Banjarnegara Regency, only 2 which came from public reports and 12 findings from the supervisory agency and its staff. Regarding evidence, Bawaslu also has difficulty obtaining evidence because Bawaslu does not have the authority to confiscate evidence, as a result the alleged violation does not meet the material requirements.

The second obstacle is the rule itself, the rules that have multiple interpretations cause $H R$ difficulties in implementing the articles that must be suspected in suspected election violations. In addition to the interpretation of the rules, there are also many rules that severely limit the subject of law, this makes it very difficult to impose on the perpetrator of the violation, then also the same violation but the tempo is different also makes the violation difficult to follow up. The third obstacle is disagreement between institutions in the integrated law enforcement center (Gakkumdu), namely the Bawaslu, the Police and the Attorney General's Office, this makes it difficult for the case to proceed to the next stage. The fourth obstacle is the limited time in handling the election crime.

Bawaslu of Banjarnegara Regency in overcoming the obstacles that occurred continues to try as much as possible in following up on suspected violations either originating from the findings of the supervisory agency or reports from the public. Bearing in mind that the difficulty of handling in prosecuting alleged violations of criminal acts Election Bawaslu maximizes preventive actions through various channels, media, and always coordinates both vertically with Bawaslu of Central Java Province and coordinates horizontally with all parties involved in Banjarnegara Regency in order to minimize potential - potential violation.

\section{Closing}

In organizing elections, law enforcement against criminal acts in legislative elections faces many obstacles, such as: a). The failure to fulfill the formal and material requirements of the alleged violation of election crimes, both from the findings of supervisors and public reports, makes it difficult to follow up on the alleged violations; b). multi-interpretative regulations cause human resource difficulties in applying the articles that must be suspected in suspected election violations; c). disagreements between institutions in the integrated law enforcement center (Gakkumdu); d). limited time for handling election crimes.

Bawaslu of Banjarnegara Regency in overcoming obstacles keeps trying as much as possible to follow up on suspected violations, maximizing preventive actions through various channels, media, and always coordinates both vertically with Bawaslu of Central Java Province and coordinates horizontally with all related parties in Banjarnegara Regency in the framework of minimize potential violations.

The community as the owner of sovereignty must understand the importance of maintaining and participating in the democratic process, so that this process can be carried out objectively, abundantly and fairly, so as to create democratic, quality and dignified elections. Regulations that are ambiguous and still cause multiple 
interpretations can be improved so that law enforcement can be maximized as possible. In order to improve the performance, integrity and professionalism of human resources in enforcement of election crimes, capacity building is needed frequently.

\section{References}

\section{Journals}

[1] Ika Yuana Darmayanti, Law Politics Of Legislative Election, Jurnal Daulat Hukum, Vol. 2, No. 2 (2019), url: /jurnal.unissula.ac.id/index.php/RH/article/view/5414/3341

[2] Iva Amiroch, Critical Study Relevance of Act No. 10 of 2016 with Government Regulation No. 151 of 2000, Jurnal Daulat Hukum Vol. 1 No. 4 (2018) url:http://jurnal.unissula.ac.id/index.php/RH/article/view/3929/2791

[3] Nurul Fuji Sri Hastuti and Jawade Hafidz, Implementation Of Article 240 Paragraph (1) Letters G Act No. 7 Of 2017 In The Making Of Combating Corruption Crime In Legislative Institutions (Case Study in KPU of Central Java), Jurnal Daulat Hukum Vo. 2 No. 2 (2019) url: http://jurnal.unissula.ac.id/index.php/RH/article/view/3340/2469

[4] Nur Muchammad, Munsharif Abdul Chalim, Analysis of Criminal Liability Crime of Legislative Elections (Case Study of Legislative Elections in Semarang), Jurnal Daulat Hukum Vol.2 No 4 (2019) url: http: /jurnal.unissula.ac.id/index.php/RH/article/view/4210/2916

[5] Sri Herlina and Umar Ma'ruf (Law Enforcement Against Elections Crime During Electoral Campaign 2019 (Case Study In Bawaslu of Banjarmasin City), Jurnal $\begin{array}{lllll}\text { Daulat Hukum, } & \text { Vol. } & 2 & \text { No } & 319\end{array}$ http://jurnal.unissula.ac.id/index.php/RH/article/view/5656/3381

[6] Yudhi Atmaja, Ira Alia Maerani, Money Politics In The Electoral Law And The Law Of Election, Jurnal Daulat Hukum, Vo. 2 No. 2 (2019) url:http://jurnal.unissula.ac.id/index.php/RH/article/view/5546

\section{Books}

[1] Firmanzah. (2010). Persaingan, Legitimasi Kekuasaan, dan Marketing Politik. Jakarta: Erlangga

[2] Hafidz, Masykurudin. (2019). Menguatkan Partisipasi Masyarakat dalam Pengawasan Pemilu Serentak 2019. Jakarta: Bawaslu

[3] Husein, Harun. (2014). Pemilu Indonesia; Fakta, Angka, Analisis, dan Studi Banding. Jakarta: Perludem

[4] M. Afifudin. (2020). Membumikan Pengawasan Pemilu. Jakarta: Kompas Gramedia

[5] Minan, Ahsanul. (2019) Perihal Penegakan Hukum Pemilu. Jakarta: Bawaslu

[6] Moh. Mahfud MD. (2018). Politik Hukum Di Indonesia, Ed. Rev. 8. Depok: Rajawali Pers

[7] Mulyadi, Dedi. (2012). Kebijakan Legislasi Tentang Sanksi Pidana Pemilu Legislatif Di Indonesia Dalam Perspektif Demokrasi. Jakarta: Gramata Publising

[8] Pettalolo, Ratna Dewi. (2019). Perihal Penegakan Hukum Pemilu. Jakarta: Bawaslu 
[9] Raharjo, Satjipto. (2012). IImu Hukum Cetakan Ke VII. Bandung: PT Cipta Aditya Bakti

[10] Riwanto, Agus. (2016). Hukum Partai Politik dan Hukum Pemilu di Indonesia. Yogyakarta: Thafa Media

[11] Soekanto, Soerjono. (2012). Faktor yang Mempengaruhi Penegakan Hukum. Jakarta: Rajawali Press

[12] Veri Junaidi, et.all. (2013). Politik Hukum Sistem Pemilu: Potret Keterbukaan dan Partisipasi Publik dalam Penyusunan Undang-Undang Nomor 8 Tahun 2012 tentang Pemilihan UMUM Anggota DPR, DPD, dan DPRD. Jakarta: Yayasan Perludem 